\title{
Enteroviral pharyngitis diagnosed by reverse transcriptase-polymerase chain reaction
}

\author{
M Sharland, J Hodgson, E G Davies, J Booth, S Jeffery
}

\begin{abstract}
The role of enteroviruses in childhood pharyngitis was investigated using enteroviral specific reverse transcriptasepolymerase chain reaction (RT-PCR). Viral/bacterial throat swabs were taken from 50 children with acute pharyngitis and 26 controls. A positive culture was identified in only $26 \%$ of children with pharyngitis (adenovirus 10\%, group A streptococci $2 \%$ ), and none of the controls. Enteroviral RT-PCR was positive in $8 \%$ of the pharyngitis group and none of the controls. Enteroviruses are an important cause of pharyngitis in childhood. (Arch Dis Child 1996; 74: 462-463)
\end{abstract}

Keywords: enterovirus, pharyngitis, polymerase chain reaction.

Pharyngitis is one of the commonest illnesses in childhood. While nasopharyngitis usually has a viral aetiology, pharyngitis may be caused by a range of agents including group A streptococci, adenoviruses, influenza, parainfluenza, and Epstein-Barr viruses, and Mycoplasma pneumoniae. Enteroviruses have been recognised as an important cause of pharyngitis, but acute infections are difficult to diagnose using either culture or serology. ${ }^{1}$ A highly conserved $5^{\prime}$ region of the enteroviral genome has recently been identified, allowing amplification of enteroviral specific sequences using reverse transcriptase-polymerase chain reaction (RTPCR). ${ }^{23}$ The purpose of this study was to identify the viral and bacterial causes of pharyngitis in the local population, and to investigate the role of enteroviruses in this condition.

St George's Hospital, London SW17:

Paediatric Infectious

Diseases Unit

$M$ Sharland

E G Davies

$S$ Jeffery

Department of

Virology

J Hodgson

J Booth

Correspondence to:

Dr M Sharland, Paediatric

Infectious Diseases Unit, 5th

Floor Lanesborough Wing.

St George's Hospital,

Blackshaw Road, London

SW17 0QT.

Accepted 23 January 1996 viral throat swabs were taken from children aged 1-10 years with pharyngitis. Standard culture of both swabs was performed in the microbiology and virology laboratories. Viral swabs were cultured in rhesus monkey kidney (RMK) and human epithelial (HEp) cell lines for 14 days. A $2 \mathrm{ml}$ aliquot of the RMK tissue culture only was stored at $-70^{\circ} \mathrm{C}$. Control bacterial and viral swabs were taken during anaesthesia from children admitted for routine minor surgery. Ethics consent was obtained for the study.
MOLECULAR METHODS

Briefly, $100 \mu l$ aliquots from the rhesus monkey kidney tissue culture specimens were thawed and pretreated with RNasin and dithiothreitol. Nucleic acid was extracted using phenol:chloroform, and the RNA precipitated using ethanol. All RT and PCR steps were performed blind. A $20 \mu l$ reverse transcriptase (RT) mix was made from $14 \mu \mathrm{l}$ of sample, $2 \mu \mathrm{l}$ of nucleoside triphosphates, $2 \mu$ l of RT buffer, $0.5 \mathrm{U}$ of RNAsin, $0.2 \mu \mathrm{l}$ of random hexamers, $50 \mathrm{U}$ murine Moloney leukaemia virus (MMLV) RT (BRL), and $1.5 \mu \mathrm{l}$ of $50 \mathrm{mM}$ $\mathrm{MgCl}_{2}$. This was incubated at $42^{\circ} \mathrm{C}$ for 15 min, $99^{\circ} \mathrm{C}$ for $5 \mathrm{~min}$, and $4^{\circ} \mathrm{C}$ for $5 \mathrm{~min}$. First round PCR reaction was in $100 \mu$ l, using 0.2 units of SuperTaq (HT Biotechnology), with $0.5 \mu \mathrm{m}$ of primer $\mathrm{E} 1^{4}$ and $\mathrm{CX} 3^{5}$ with a final magnesium concentration of $1.5 \mathrm{mM}$. Two minutes at $95^{\circ} \mathrm{C}$ were followed by 40 cycles of $1 \mathrm{~min} 95^{\circ} \mathrm{C} / 1 \mathrm{~min} 60^{\circ} \mathrm{C}$. Nested PCR used 2 $\mu l$ of first round product in a $50 \mu \mathrm{lmix}$ containing $0.15 \mathrm{U}$ of SuperTaq, $1.5 \mathrm{mM} \mathrm{MgCl}_{2}$, $0 \cdot 15 \mu \mathrm{M} \mathrm{E} 2,{ }^{4}$ and $\mathrm{CX} 10^{5}$ for 30 cycles.

The PCR product $(15 \mu \mathrm{l})$ was electrophoresed in $1.5 \%$ agarose gels. DNA was visualised with ethidium bromide and ultraviolet. First round products were 287 base pairs, and nested products were 154 base pairs. DNA was transferred to Zetaprobe by alkali transfer with $0.4 \mathrm{M} \mathrm{NaOH}$. The oligo E3 (100 ng) was endlabelled with r32P CTP, and used to probe the filters. ${ }^{4}$ Prehybridisation was at $37^{\circ} \mathrm{C}$ for $1 \mathrm{~h}$, and hybridisation for $2 \mathrm{~h}$, in $5 \mathrm{ml}$ $20 \times$ SSPE, $1 \mathrm{ml} 100 \times$ Denhardt's solution, and $1 \mathrm{ml} 10 \%$ SDS made up to $20 \mathrm{ml}$ in distilled water. Membranes were washed in $2 \times$ SSC with $0 \cdot 1 \% \operatorname{SDS}$ up to $48^{\circ} \mathrm{C}$ then exposed overnight to $x$ ray film.

The detection limit of the enteroviral nested PCR was analysed using the positive control of coxsackie B3/030893 $\left(10^{7} \mathrm{TCID}_{50} / \mathrm{ml}\right)$, and was shown to be approximately $0.5 \mathrm{TCID}_{50}$. As published primer pairs were used, not all enteroviral serotypes were tested. Several other positive tissue cultures infected with nonenteroviral DNA and RNA viruses were tested, but no positive results were obtained. Standard negative controls and precautions to avoid contamination were used.

\section{Results}

Over the one year period 50 children with pharyngitis were swabbed (26 M, $24 \mathrm{~F}$; mean age $4 \cdot 1$ years, range 1 to 10 years). Control throat swabs were taken from 26 children (22 $M, 4 \mathrm{~F}$; mean age 4.7 years, range 1 to 10 years). All swabs from control children were negative for bacterial culture, viral cell culture, and 
Frequency of organisms identified from pharyngitis group

\begin{tabular}{ll}
\hline Organism isolated & Frequency (\%) \\
\hline Streptococcus pyogenes & $1(2)$ \\
Streptococcus pneumoniae & $1(2)$ \\
Haemophilus influenzae & $2(4)$ \\
Influenza A & $1(2)$ \\
Influenza B & $1(2)$ \\
Adenovirus & $5(10)$ \\
Parainfluenza 3 & $2(4)$
\end{tabular}

enteroviral PCR. A positive viral or bacterial culture was identified in only 13 children (26\%) (table). There were no dual positive cultures. No positive case of enteroviral infection was detected by viral cell culture.

Four samples $(8 \%)$ were positive on enteroviral nested PCR. All four specimens were repeated on the RMK tube frozen specimen, and confirmed to be positive on a second nested PCR. All four samples that were positive on nested PCR were also positive on blotting. No sample was positive by blotting, and not by nested PCR.

\section{Discussion}

In this prospective study, a positive viral or bacterial diagnosis was obtained in only one third of children studied. Group A streptococcal infection was very rare (2\%). Mycoplasma, chlamydia, Epstein-Barr virus, and anaerobic infections would not have been detected. The enteroviral nested PCR gave clear bands on agarose gel and Southern blots, detecting samples that were negative by cell culture. Although it is possible that these positives were due to contamination, all repeat PCR reactions gave identical results, despite their lack of diagnosis in cell culture. Only the RMK cell culture was analysed by PCR, as it is unusual for enteroviruses to grow just in HEp cell lines.

There have been few prospective studies of the relative importance of different viral infections in childhood pharyngitis. Adenovirus was the commonest pathogen identified in this study, confirming a previous report. ${ }^{1}$ Enteroviral infections were the second commonest documented infection, confirming their importance as a cause of pharyngitis in childhood.

1 Cherry JD. Pharyngitis (pharyngitis, tonsillitis, tonsillopharyngitis, and nasopharyngitis). In: Feigin RD, Cherry $\mathrm{JD}$, eds. Textbook of paediatric infectious diseases, 3rd ed. Philadelphia: W B Saunders, 1992: 159-66.

2 Rotbart HA. Enzymatic RNA amplification of the enteroviruses. 于 Clin Microbiol 1990; 28: 438-42.

3 Nicholson F, Neetoo G, Aiyar S, Banatvala J, Muir P. Detection of enterovirus RNA in clinical samples by nested polymerase chain reaction for rapid diagnosis of enteroviral infections. I Virol Methods 1994; 48: 155-66.

4 Chapman NM, Tracy S, Gauntt CJ, Fortmueller U. Molecular detection and identification of enteroviruses using enzymatic amplification and nucleic acid hybridisation. $\mathcal{F}$ Clin Microbiol 1994; 28: 843-50.

5 Severini GM, Mestroni L, Falaschi A, Camerini F, Giacca $M$. Nested polymerase chain reaction for high sensitivity detection of enteroviral RNA in biological samples. $\mathcal{f}$ Clin Microbiol 1993; 31: 1345-9. 